University of Nebraska - Lincoln

DigitalCommons@University of Nebraska - Lincoln

USDA National Wildlife Research Center - Staff Publications
U.S. Department of Agriculture: Animal and Plant Health Inspection Service

October 2006

\title{
Investigating the feasibility of a passive tracking index for monitoring wildlife in the Lower Omo Valley, Ethiopia
}

Richard M. Engeman

USDA-APHIS-Wildlife Services, s_r100@yahoo.com

Paul Evangilista

Colorado State University, Fort Collins

Follow this and additional works at: https://digitalcommons.unl.edu/icwdm_usdanwrc

Part of the Environmental Sciences Commons

Engeman, Richard M. and Evangilista, Paul, "Investigating the feasibility of a passive tracking index for monitoring wildlife in the Lower Omo Valley, Ethiopia" (2006). USDA National Wildlife Research Center Staff Publications. 622.

https://digitalcommons.unl.edu/icwdm_usdanwrc/622

This Article is brought to you for free and open access by the U.S. Department of Agriculture: Animal and Plant Health Inspection Service at DigitalCommons@University of Nebraska - Lincoln. It has been accepted for inclusion in USDA National Wildlife Research Center - Staff Publications by an authorized administrator of DigitalCommons@University of Nebraska - Lincoln. 


\title{
Investigating the feasibility of a passive tracking index for monitoring wildlife in the Lower Omo Valley, Ethiopia
}

\author{
Richard M. Engeman ${ }^{1 *}$ and Paul Evangilista ${ }^{2}$ \\ ${ }^{1}$ National Wildlife Research Center, 4101 LaPorte Avenue, Fort Collins, CO 80521-2154 and ${ }^{2}$ Natural Resource Ecology Laboratory, Colorado \\ State University, Fort Collins, CO 80523-1499, U.S.A.
}

\begin{abstract}
In many places in Africa, constraints in human, financial and physical resources are common problems that limit the effectiveness of wildlife researchers and managers. In an attempt to identify a useful tool for monitoring African wildlife populations, we tested a passive tracking index (PTI) methodology on a unique wildlife resource area in the Lower Omo Valley, Ethiopia. The methodology had previously proved valuable for monitoring a wide variety of wildlife species, including ungulates and carnivores in North America and Australia. Two ungulates (lesser kudu and dikdik), a carnivore (hyaena), a primate (baboon), and a ground foraging bird (guineafowl) were simultaneously indexed. In addition, single observations were recorded for genet, serval and caracal. The species indexed also represent the broad needs for monitoring wildlife. The mammal species are of economic importance to the region through sport hunting. Two of the species, hyaenas and baboons, potentially conflict with human agricultural interests through depredations on livestock and crop production. Anthrax periodically decimates the wildlife in the Lower Omo Valley, Ethiopia, but losses of many species are difficult to observe or quantitatively document. The PTI is a simple-to-apply, easyto-calculate means to quantify simultaneously population trends for multiple species, and particularly applicable to sustainable harvest by sport hunting, human-wildlife conflicts, and impacts and recovery from wildlife disease.
\end{abstract}

Key words: game management, human-wildlife conflict, population monitoring, wildlife disease

\section{Résumé}

A de nombreux endroits en Afrique, les contraintes qui s'exercent sur les ressources humaines, financières et

*Correspondence: Tel.: (970) 266 6091; Fax: (970) 266 6089; E-mail: richard.m.engeman@aphis.usda.gov physiques sont des problèmes communs, qui limitent l'efficacité des chercheurs et des gestionnaires de la faune sauvage. Pour tenter d'identifier un outil pratique pour la surveillance régulière des populations de la faune africaine, nous avons testé une méthodologie pour un Index de suivi passif (passive tracking index - PTI) dans une zone ressource unique de faune dans la basse vallée de l'Omo, en Ethiopie. La méthodologie s'était auparavant avérée valable pour la surveillance continue d'une grande variété d'espèces sauvages, y compris des ongulés et des carnivores en Amérique du Nord et en Australie. Deux ongulés (le petit koudou et le dik-dik), un carnivore (la hyène), un primate (le babouin) et un oiseau qui se nourrit au sol (la pintade) ont été indexés simultanément. De plus, furent rapportées des observations uniques de genette, serval et caracal. Les espèces indexées représentent aussi les besoins généraux pour la surveillance de la faune. Les espèces de mammifères ont une importance économique dans la région en raison de la chasse sportive. Deux des espèces, les hyènes et les babouins, entrent parfois en conflit avec les intérêts humains par les déprédations qu'elles causent au bétail et aux productions agricoles. L'anthrax décime périodiquement la faune sauvage dans la basse vallée de l'Omo, mais il est difficile de constater les pertes pour de nombreuses espèces et encore plus de les quantifier. Le PTI est un moyen d'application simple, facile à calculer pour quantifier simultanément les tendances des populations de multiples espèces, et il est particulièrement intéressant à appliquer pour les prélèvements durables lors de chasses sportives, pour les conflits hommes-faune sauvage, et dans la mesure de l'impact et de la restauration suite à des maladies de la faune.

\section{Introduction}

Monitoring populations is a critical component of most wildlife management plans. In Africa, restrictions in 
resources are a recurring problem for wildlife managers and researchers. Lack of equipment and trained personnel requires field methods to be simple and inexpensive, yet effective in detecting changes in wildlife densities. This is especially true in the Lower Omo Valley, Ethiopia, where a diverse array of wildlife species persists, but few resources and materials are available to quantify trends in wildlife populations.

Despite growing human and livestock populations among local pastoral tribes, recurring warfare between the Bume and Hamar Tribes has inadvertently created a safe haven for wildlife in the Lower Omo Valley. Fearing livestock theft and reprisals, local tribes avoid cattle grazing along territorial boundaries, creating a large buffer zone of relatively undisturbed flora and fauna. European expeditions as far back as the late 1800s noted the tribal wars and the buffer zone between territories (Butzer, 1971). During times of crises, such as drought, treaties are often made opening the buffer zone to livestock grazing and tribal hunting. Other times, the area of the buffer zone increases with the intensity of conflict, allowing wildlife to exist with little human disturbance.

This remote area of Ethiopia is well known for its sport hunting opportunities. Mellon (1996) remarked that the Lower Omo Valley contained more wildlife than any of the national parks or game reserves he encountered in Kenya. Highly regulated sport hunting is a major revenue source for game management and regional governments. Only a limited number of wildlife species are allowed to be harvested annually, which is determined by highly variable and unreliable observations. Managers who monitor wildlife populations for hunting and conservation often have inadequate training, understanding, or resources to implement complex density estimations or other monitoring methods. Moreover, wildlife populations in this area are periodically decimated by anthrax epidemics (HughJones \& De Vos, 2002). Both contexts have created the need for a rapid, easy-to-conduct monitoring methodology that field personnel can employ with the consistency needed for valid quantitative results.

Prior to operationally applying survey methodologies to new habitats or species, field testing should be conducted, even though the methods have proved successful elsewhere (Engeman \& Witmer, 2000). We tested a passive tracking index (PTI) in the Lower Omo Valley that has been successfully applied in North America and Australia for monitoring canids (Allen, Engeman \& Krupa, 1996; Engeman et al., 2000, 2002), other carnivores (Engeman et al., 2003a,b), macropods and other marsupials (Allen \& Engeman, 1995), and ungulates (Engeman et al., 2000, 2001, 2002). In this study, we describe results of our application of PTI methodology in the Lower Omo Valley, and comment on its applicability as a general monitoring method there.

\section{Methods}

\section{Lower Omo Valley}

The Omo River flows from the Blue Nile and Sobat watersheds in the Ethiopian highlands south to Lake Turkana. Our study site in the Lower Omo Valley lies in a remote section of south-west Ethiopia $\left(05^{\circ} 30^{\prime} \mathrm{N}, 36^{\circ} 00^{\prime} \mathrm{E}\right.$ to $05^{\circ} 00^{\prime} \mathrm{N}, 36^{\circ} 3^{\prime} \mathrm{E}$ ), approximately $75 \mathrm{~km}$ north of the Ethiopia/Kenya border. This biologically rich region supports one of the largest concentrations of wildlife in East Africa, with over 60 mammalian species found there (although many are migratory or confined to specific habitat/vegetation types).

Our research was conducted in savanna bushlands on the east side of the Omo River. The area shares the borders of four major pastoralist territories and their 100,000-plus head of domestic livestock (Thouless, 1995). The Hamar tribe of over 30,000 people resides on the eastern border of the study area and beyond. The Bume Tribe of about 20,000 inhabits the western border and is separated from the Hamar by the Omo River. The Galeb Tribe of about 25,000 is on the south of the study area, rarely using it except for hunting. The Karo tribe of about 1,000 lives on the Omo River on the north of the study area and try to maintain peaceful relations with neighbouring tribes (Petros, 1994).

\section{PTI method}

A transect comprising twenty tracking plots randomly located along a low-use dirt road was used as an efficient design for sampling the area (Pearson \& Ruggiero, 2003). Plots $1.5 \mathrm{~m}$ long were raked and smoothed to produce a good tracking base that spanned the road-width $(c .3 \mathrm{~m}$ average), with a minimum inter-plot spacing of $0.5 \mathrm{~km}$. The soil substrate was fine-grained, providing an excellent surface for recording tracks. After $24 \mathrm{~h}$, the plots were examined for tracks and resurfaced (tracks erased, soil smoothed) for the next day's observations. At each plot, the number of track sets (number of intrusions) by each 
animal species was recorded. A tracker from the local hunting concession identified tracks. We observed each plot for three consecutive days.

\section{Analyses}

The PTIs and associated variances were calculated according to Engeman (2005) where a mixed linear model (e.g. McLean, Sanders \& Stroup, 1991; Wolfinger, Tobias \& Sall, 1991) is used to describe the number of intrusions on each plot each day, and no assumptions of independence among plots or days are made. The mean number of track intrusions on each plot by each species is calculated for each day. The index values are the means of the daily means for each species:

$$
\mathrm{PTI}=\frac{1}{d} \sum_{j=1}^{d} \frac{1}{p_{j}} \sum_{i=1}^{p_{j}} x_{i j},
$$

where the $x_{i j}$ represents the number of intrusions by a given species on the ith plot on the $j$ th day, $d$ is the number of days of observation, and $p_{j}$ is the number of plots contributing data on the $j$ th day. SAS PROC VARCOMP with a restricted maximum likelihood estimation procedure (SAS Institute, 1996) was used to calculate the variance components (Searle, Casella \& Mcculloch, 1992) needed in the PTI variance estimation formula (Engeman, 2005):

$$
\operatorname{var}(\mathrm{PTI})=\frac{\sigma_{\mathrm{p}}^{2}}{d} \sum_{j=1}^{d} \frac{1}{p_{j}}+\frac{\sigma_{\mathrm{d}}^{2}}{d}+\frac{\sigma_{\mathrm{e}}^{2}}{d^{2}} \sum_{j=1}^{d} \frac{1}{p_{j}}
$$

where the $\sigma_{\mathrm{p}}^{2}, \sigma_{\mathrm{d}}^{2}$ and $\sigma_{\mathrm{e}}^{2}$ are, respectively, the components for between-plot variability, daily variability and random observational variability associated with each plot each day.

\section{Results}

A rainstorm occurred during the first day of observations. Although tracks were still recorded on the plots, the observations may represent $<24 \mathrm{~h}$ accumulation of spoor, in contrast to the other days of observations. The PTI is intended to sample temporal changes in activity, assuming equal time lengths each day for recording tracks, with the degree of fluctuations reflected in variance estimates. For illustrative purposes, we calculated index values using data from all 3 days of observation (Table 1), as well as using only the observations from the two rain-free (full-length
Table 1 Passive tracking index (PTI) values for animals monitored in the Lower Omo Valley, Ethiopia. Tracking plots were monitored for three consecutive days. Index values calculated using all three days of data include data from the first day when a rainstorm may have erased some data. Index values were also calculated for the

\begin{tabular}{|c|c|c|c|c|c|c|}
\hline \multirow[b]{2}{*}{ Species } & \multicolumn{3}{|c|}{$\begin{array}{l}\text { PTI calculated using } \\
3 \text { days of data, including } \\
\text { a day with rainstorm }\end{array}$} & \multicolumn{3}{|c|}{$\begin{array}{l}\text { PTI calculated using } \\
2 \text { days of data, excluding } \\
\text { a day with rainstorm }\end{array}$} \\
\hline & PTI & Variance & SE & PTI & Variance & SE \\
\hline Baboon & 0.083 & 0.007 & 0.084 & NA & NA & NA \\
\hline Guineafowl & 0.217 & 0.014 & 0.117 & 0.275 & 0.008 & 0.089 \\
\hline Lesser kudu & 0.067 & 0.001 & 0.032 & 0.075 & 0.001 & 0.028 \\
\hline Dikdik & 0.233 & 0.021 & 0.145 & 0.350 & 0.011 & 0.102 \\
\hline Hyaena & 0.150 & 0.016 & 0.128 & 0.225 & 0.020 & 0.142 \\
\hline
\end{tabular}
last two days, excluding data from the day with the rainstorm

observation) days (Table 1). Two days of observation has consistently been found to be sufficient and practical for indexing purposes in previous applications of the PTI methodology (e.g. Engeman et al., 2003a,b).

Indices were calculated for lesser kudu (Tragelaphus imberbis Blyth), Guenther's dikdik (Madoqua guentheri Thomas), hyaena (Hyaena hyaena L. or Crocuta crocuta Erxleben), baboons (Papio anubis Lesson) and guineafowl (Acryllium vulturinum Hardwicke). The PTIs based on 2 days of data for these four species (Table 1) were up to $50 \%$ larger than the PTIs when the first day of observations from the rain day were included in the calculations.

Besides the above species with repeated observations of spoor, it is noteworthy that tracks were recorded for three other carnivores. A track intrusion into a plot was observed one time each for a genet (Genetta felina L.) and two cat species, caracal (Caracal caracal Schreber) and serval (Leptailurus serval Schreber).

\section{Discussion}

A simple, inexpensive and effective method for monitoring wildlife is desperately needed for managing wildlife in the Lower Omo Valley (Jachmann, 2001). Wildlife species in the Lower Omo Valley are faced with impacts from tribal warfare, poaching, conflicts with human agriculture and wildlife disease. Assessing these impacts and placing limits on sustainable uses such as sport hunting with very limited fiscal, physical and educated human resources present a great challenge for conserving and managing the wildlife resources in the area. 
Our probe into indexing wildlife in the Lower Omo Valley succeeded in indexing two ungulate species, a carnivore and a terrestrial bird. Population information derived from only these species would be valuable for general management purposes. To index some species would require seasonal applications relative to migratory periods or within pockets of confined habitats. Our index values might be considered baseline values for comparison for future monitoring efforts. However, we advise permanent plot locations be defined for efficiently monitoring population trends (e.g. Ryan \& Heyward, 2003). While the PTI monitors multiple species simultaneously, it is not appropriate to compare index values between species (Engeman, 2005). Clearly two species with the same abundances may have different activity levels, thereby producing different tracking rates and index values. However, population trends identified using the PTI over the same timeframe could be compared between species.

The lesser kudu in particular, and also the other indexed mammals, are game species of regional economic importance through sport hunting, and their populations must be managed for a sustainable harvest. The respective license fees for these species (US\$1500 for lesser kudu, US\$50 for baboon, US\$100 for dikdik, US\$90 for hyaena, US\$180 for serval cat, and US\$200 for caracal) go directly to the regional government, with other economic factors such as the (large) amount paid for the local hunting concession rights also benefiting the region (Ethiopian Wildlife Conservation Organisation, 1996). Revenues generated by the safari hunting industry are enough to fund operation of the region's protected areas, with surpluses assisting community development projects. A simple management tool for indexing populations would provide more informed management towards sustainable harvests and stable income for the region.

Human conflicts with wildlife pose different management issues to which monitoring data can be applied (Engeman \& Witmer, 2000). For example, hyaenas were readily monitored and they are prominent among the animals in conflict with humans through livestock predation and occasional attacks on humans. Their take of calves, sheep, and goats significantly impacts the economic situation for pastoralist families (P. Evangilista and J. Rousses, personal observation). Baboons are also problem animals through destruction of agricultural crops, with the Karo tribe particularly affected by depredations to sorghum and maize crops.

The PTI methodology would also be useful for monitoring the effects of disease on wildlife populations. For example, cutaneous anthrax decimated the wildlife (and livestock) in the Lower Omo Valley in 2000 and 2001 (N. Rousses, Ethiopian Rift Valley Safaris, personal communication). The regional government, along with the Ethiopian Wildlife Conservation Organization and personnel from Ethiopian Rift Valley Safaris, burned over 2000 lesser kudu carcasses (J. Rousses, personal communication). Hyaenas and baboons were believed to also be hard-hit, but baboons typically die in thick cover and hyaenas in their dens. Index values would not only help verify the declines and subsequent recoveries for species like the lesser kudu where losses are obvious, but also for those species where carcasses are not so readily apparent. Similarly, the changing impacts to wildlife resources from changing intensity of inter-tribal warfare would also be reflected by the monitored species.

Populations of African cats are particularly difficult to monitor (e.g. Jachmann, 2001). Detection of two cat species (caracal and serval) on our tracking plots suggests indexing populations may be possible by expanding the survey. While this merits further investigation, these results highlight another advantage of the PTI methodology, detecting cryptic and other difficult-to-detect species (e.g. Allen \& Engeman, 1995).

The PTI, being based on counting daily movements of animals across tracking stations, is unlikely to influence normal animal activity. We found no track evidence that any species we monitored either avoided or were attracted to tracking plots. To detect presence or to index activity with alternative assessment methods could require a major effort using perhaps a combination of methods such as spotlight counts, pellet or scat counts, line transect counts or aerial surveys. The PTI offers a means to monitor the unique wildlife resource in the Lower Omo Valley without expensive or high-tech equipment, and without requiring a high degree of technical expertise by field personnel.

\section{Acknowledgements}

The authors would like to thank Nassos Rousses and Jason Rousses of Ethiopian Rift Valley Safaris, The Murulle Foundation, Dr Nico Loannou and Richard Flack for their help with field data collection. K. Fagerstone and J.R. Mason provided helpful reviews.

\section{References}

AlLen, L. \& Engeman, R. (1995) Assessing the impact of dingo predation on wildlife populations. In: 10th Australian Vertebrate 
Pest Control Conference (Ed. M. STAтHAM). Tasmanian Department of Primary Industries and Fisheries, Hobart.

Alden, L., Engeman, R. \& Krupa, H. (1996) Evaluation of three relative abundance indices for assessing dingo populations. Wildl. Res. 23, 197-206.

Butzer, K.J. (1971) Recent History of an Ethiopian Delta: the Omo River and the Level of Lake Rudolf. The Department of Geography, University of Chicago, Chicago, IL.

ENGEMAN, R.M. (2005) A methodological and analytical paradigm for indexing animal populations applicable to many species and observation methods. Wildl. Res. 32, 203-210.

ENGEMAN, R.M. \& WITMER, G.W. (2000) IPM strategies: indexing difficult to monitor populations of pest species. Verteb. Pest Conf. 19, 183-189.

Engeman, R.M., Pipas, M.J., Gruver, K.S. \& Allen, L. (2000) Monitoring coyote populations with a passive activity index. Wildl. Res. 27, 553-557.

Engeman, R.M., Constantin, B., Nelson, M., Woolard, J. \& Bourassa, J. (2001) Monitoring changes in feral swine population and spatial distribution of activity. Environ. Conserv. 28, 235-240.

Engeman, R.M., Pipas, M.J., Gruver, K.S., Bourassa, J. \& Allen, L. (2002) Plot placement when using a passive tracking index to simultaneously monitor multiple species of animals. Wildl. Res. 29, 85-90.

Engeman, R.M., Christensen, K.L. Pipas, M.J. \& Bergman, D.L. (2003a) Population monitoring in support of a rabies vaccination program for skunks in Arizona. J. Wildl. Dis. 39, 746-750.

Engeman, R.M., Martin, R.E., Constantin, B., Noel, R. \& Woolard, J. (2003b) Monitoring predators to optimize turtle nest protection through control. Biol. Conserv. 113, 171-178.

Ethiopian WiLdlife Conservation Organisation (1996) Sport Hunting Guidelines in Southern Ethiopia. Ethiopian Wildlife Conservation Organisation, Addis Ababa.
Hugh-Jones, M.E. \& De Vos, V. (2002) Anthrax and wildlife. Rev. Sci. Tech. Off. Int. Epiz. 21, 359-383.

Jachmann, H. (2001) Estimating Abundance of African Wildlife: an Aid to Adaptive Management. Kluwer Academic Publishers, Boston, MA.

McLean, R., SANDERs, W. \& Stroup, W. (1991) A unified approach to mixed linear models. Am. Stat. 45, 54-64.

Mellon, J. (1996) African Hunter. Safari Press, Long Beach, CA.

PeArson, D.E. \& Ruggiero, L.F. (2003) Transect versus grid trapping arrangements for sampling small mammal communities. Wildl. Soc. Bull. 31, 454-459.

Petros, G. (1994) The Karo of the Lower Omo Valley: subsistence, social organization and relations with neighboring groups. Thesis, Department of Anthropology, Addis Ababa University, Addis Ababa, Ethiopia.

Ryan, D.A. \& Heyward, A. (2003) Improving the precision of longitudinal ecological surveys using precisely defined observational units. Environmetrics 14, 283-293.

SAS Institute (1996) SAS/STAT User's Guide. SAS Institute, Cary, NC.

Searle, S.R., Casella, G. \& Mcculloch, C.E. (1992) Variance Components. Wiley \& Sons, New York.

Thouless, C.R. (1995) Aerial Survey of Wildlife in Omo Valley, Chew Bahir and Borana Areas of Southern Ethiopia. Ecosystem Consultants, London.

Wolfinger, R., Tobias, R. \& SALL, J. (1991) Mixed models: a future direction. In: 16th SAS Users Group Conference (Ed. M. RosENBERG). SAS Institute, Carey, NC.

(Manuscript accepted 25 August 2006)

doi: 10.1111/j.1365-2028.2006.00695.x 